\title{
Persepsi Masyarakat Terhadap Keberadaan Peternakan Ayam Ras Petelur Di Dusun Passau Timur Desa Bukit Samang Kecamatan Sendana Kabupaten Majene
}

\author{
Muhammad Abdi ${ }^{1}$, Suhartina ${ }^{2}$, Nur Saidah Said ${ }^{3}$, Najmah Ali $^{4}$ \\ Fakultas Peternakan dan Perikanan Universitas Sulawesi Barat \\ tina_afriano@yahoo.com
}

\begin{abstract}
Abstrak
Peternakan Ayam Ras Petelur di Dusun Passau Timur Desa Bukit Samang Kecamatan Sendana, Kabupaten Majene. menunjukkan adanya isu di sekitar lingkungan peternakan. Penelitian ini bertujuan untuk mengetahui persepsi masyarakat terhadap keberadaan peternakan ayam ras petelur di Dusun Passau Timur Desa Bukit Samang Kecamatan Sendana, Kabupaten Majene. Penelitian dilaksanakan pada tanggal 01 Juli sampai 01 Agustus 2017. Jenis penelitian ini adalah penelitian kuantitatif deskriptif yang menggambarkan suatu fenomena, dalam hal ini persepsi masyarakat terhadap keberadaan peternakan ayam ras petelur. Populasi sebanyak 220 orang dan jumlah sampel sebanyak 37 orang yang ditentukan berdasarkan rumus Slovin, teknik pengambilan sampelnya dilakukan secara purposive sampling. Hasil penelitian menunjukkan bahwa persepsi masyarakat terhadap keberadaan peternakan ayam ras petelur di Dusun Passau Timur Desa Bukit Samang Kecamatan Sendana, Kabupaten Majene adalah sebagian besar merasa tidak terganggu dengan adanya peternakan ayam ras petelur.
\end{abstract}

Keywords: Persepsi, Masyarakat, Keberadaan Peternakan, Ayam Ras

\section{Pendahuluan}

Usaha peternakan unggas terutama ayam ras petelur merupakan usaha yang memiliki perkembangan yang cukup pesat. Usaha peternakan ayam petelur memberikan peranan sangat penting dalam pemenuhan kebutuhan protein hewani pada masyarakat dan berbagai keperluan industri khususnya pangan. Meningkatnya jumlah penduduk di Indonesia hingga tahun 2015 yang mencapai 254,9 juta jiwa (BPS, 2015) dan peningkatan kesadaran masyarakat Indonesia akan pentingnya protein hewani juga memberikan dampak positif terhadap perkembangan usaha di bidang peternakan ayam ras petelur. Jumlah populasi ayam ras petelur di Indonesia tahun 2015 adalah 151.419.000 ekor (BPS, 2015). Usaha peternakan ayam petelur mempunyai prospek yang bagus untuk dikembangkan karena tingginya permintaan akan produk peternakan khususnya telur. Usaha peternakan ayam ras petelur juga memberikan keuntungan yang cukup besar dan menjadi sumber pendapatan bagi banyak masyarakat di Indonesia. Namun demikian, usaha peternakan ayam ras petelur juga menghasilkan limbah yang dapat menjadi sumber pencemaran, seiring dengan kebijakan otonomi, maka pengembangan usaha peternakan yang dapat meminimalkan limbah peternakan perlu dilakukan oleh pemerintah kabupaten/ kota untuk menjaga kenyamanan permukiman masyarakatnya. Salah satu upaya yang dapat dilakukan adalah memanfaatkan limbah peternakan sehingga dapat memberi nilai tambah bagi usaha tersebut.

Limbah peternakan dianggap suatu bahan yang tidak penting dan tidak bernilai ekonomi. Padahal jika dikaji dan diolah, limbah peternakan dapat diolah menjadi beberapa produk baru yang bernilai ekonomi tinggi. Limbah peternakan meliputi semua kotoran yang dihasilkan dari suatu kegiatan usaha peternakan baik berupa limbah padat dan cairan, gas, maupun sisa pakan. Limbah padat merupakan semua limbah yang berbentuk padatan atau dalam fase padat (kotoran ternak, ternak yang mati, atau isi perut dari pemotongan ternak). Limbah cair adalah semua limbah yang berbentuk cairan atau dalam fase cairan (air seni atau urine, air dari pencucian alat-alat). Penanganan limbah yang tidak baik akan menimbulkan keresahan dan akan menimbulkan persepsi masyarakat yang tidak baik bagi peternakan tersebut.

Persepsi yaitu penangkapan indera terhadap realitas yang diamati, kemudian disusun sebuah pengertian (konsepsi), akhirnya dilakukan prediksi atau peramalan tentang kemungkinan-kemungkinan yang akan terjadi dimasa depan (Muntansyir dan Munir, 2003). Berdasarkan uraian latar belakang tersebut di atas, maka dilakukan penelitian mengenai "Persepsi Masyarakat Terhadap Keberadaan Peternakan Ayam Ras Petelur Di Dusun Passau Timur Desa Bukit Samang Kecamatan Sendana, Kabupaten Majene”.

\section{Metodologi Penelitian}

Penelitian ini dimulai pada tanggal 01 Juli sampai 05 September 2017 di Dusun Passau Timur, Desa Bukit Saman, Kecamatan Sendana Kabupaten Majene. Alasan memilih lokasi penelitian dengan pertimbangan bahwa ada beberapa masyarakat merasa terganggu dengan bau yang berasal dari peternakan terutama masyarakat yang bermukim di sekitar kandang peternakan ayam ras petelur di Dusun Passau Timur, Desa Bukit Samang Kecamatan Sendana, Kabupaten 
Majene. Jenis penelitian ini adalah kualitatif deskriptif, yaitu jenis penelitian yang menjelaskan atau menggambarkan suatu fenomena, dalam hal ini persepsi masyarakat terhadap keberadaan peternakan ayam ras petelur di Dusun Passau Timur Desa Bukit Samang Kecamatan Sendana, Kabupaten Majene. Metode penelitian yang digunakan yaitu metode survei, yaitu dengan melakukan pendekatan langsung terhadap masyarakat yang berada di sekitar lokasi usaha peternakan ayam ras petelur tersebut.

Populasi penelitian ini adalah masyarakat Dusun Passau Timur Desa Bukit Samang Kecamatan Sendana, Kabupaten Majene yang pemukiman di sekitar 200 meter dari peternakan ayam petelur tersebut. Jumlah total populasi yang tinggal berdekatan dengan peternakan ayam ras petelur yaitu sebanyak 220 orang.

Karena jumlah populasi yang cukup besar yaitu

220 orang maka dilakukan pengambilan sampel. Untuk menentukan besarnya ukuran sampel maka dilakukan dengan menggunakan statistik deskriptif berdasarkan rumus Slovin. (Umar 2003) sebagai berikut :

$$
\mathbf{n}=\frac{N}{1+N(e)^{2}}
$$

Sehingga jumlah sampel yang didapatkan yaitu :

$$
\begin{aligned}
& \mathrm{n}=\frac{220}{1+220(15 \%)^{2}} \\
& \mathrm{n}=\frac{220}{1+220(0.15)} \\
& \mathrm{n}=\frac{189}{1+220(0.0225)} \\
& \mathrm{n}=\frac{220}{1+4,95} \\
& \mathrm{n}=\frac{220}{1+4,95} \\
& \mathrm{n}=36,97 \\
& \mathrm{n}=37 \text { orang } \\
& \text { Keterangan : } \\
& \quad \mathrm{n}=\text { Jumlah sampel } \\
& \quad \mathrm{N}=\text { Jumlah populasi } \\
& \mathrm{e}=\text { Tingkat kelonggaran }(15 \%)
\end{aligned}
$$

Tingkat kelonggaran $15 \%$ digunakan dengan dasar jumlah tidak lebih dari 2000 populasi (Sugiyono, 2003). Dengan adanya jumlah sampel yang telah ditemukan yaitu 37, maka teknik pengambilan sampelnya dilakukan secara purposive sampling.

\section{Analisis Data}

Analisis data yang digunakan pada penelitian ini statistik deskriptif dengan menggunakan pengelompokan, penyederhanaan, serta penyajian data seperti tabel distribusi frekuensi dan pengukuran dengan menggunakan skala likert. Menurut Riduwan (2008) bahwa skala likert digunakan untuk mengukur sikap, pendapat dan persepsi seseorang atau sekelompok tentang kejadian atau gejala sosial. Dengan menggunakan skala likert, maka variabel yang akan diukur dijabarkan menjadi indikator-indikator yang dapat diukur. Kemudian indikator tersebut dijadikan sebagai titik tolak untuk menyusun item-item instrumen yang

\begin{tabular}{|c|c|c|c|}
\hline No & Variabel & Sub Variabel & Indikator \\
\hline 1 & $\begin{array}{c}\text { Persepsi } \\
\text { Masyarakat }\end{array}$ & $\begin{array}{l}\text { a. Bau (penciuman) } \\
\text { b. Pencemaran Air } \\
\text { c. Limbah }\end{array}$ & $\begin{array}{l}\text { 1. Bau } \\
\text { 1. Air berbau } \\
\text { 1. Di tumpuk } \\
\text { 2. Kurangnya kebersihan }\end{array}$ \\
\hline
\end{tabular}
dapat berupa pernyataan atau pertanyaan. Setiap jawaban dihubungkan dengan bentuk pernyataan atau dukungan persepsi yang diungkapkan dengan kata-kata yang dikategorikan sebagai berikut

Sangat Terganggu : 5 Terganggu : 4 Cukup Terganggu : 3 Tidak Terganggu : 2 Sangat Tidak Terganggu : 1

\section{Instrumen Penelitian}

Adapun variabel dan indikator dalam penelitian ini adalah sebagai berikut:

Tabel 1. Variabel dan indikator Pengukuran Variabel Penelitian

\section{Bau (Penciuman)}

Untuk mengukur persepsi masyarakat terhadap limbah usaha peternakan ayam ras petelur berdasarkan bau dengan menggunakan asumsi dasar interval kelas dan rentang kelas sebagai berikut :

Nilai maksimal $=$ Skor tertinggi $\mathrm{x}$ Jumlah sampel $\mathrm{x}$ Jumlah pertanyaan

$=5 \times 37 \times 1=185$

Nilai minimal $=$ Skor terendah $\mathrm{x}$ Jumlah Sampel $\mathrm{x}$ Jumlah pertanyaan

$=1 \times 37 \times 1=33$

Rentang Kelas $=$ Jumlah nilai tertinggi - Jumlah nilai terendah

Jumlah Skor $=185-37=29,65$

Dengan nilai tersebut dapat dibuat kategori sebagai berikut :

Sangat Terganggu : $185+29.6$

Terganggu : $155,4+29.6$

Cukup Terganggu : 96,2+29.6

Tidak Terganggu : 66,6 + 29.6

Sangat Tidak Terganggu : $37+29.6$

\section{Pencemaran Air}

Untuk mengukur persepsi masyarakat terhadap limbah usaha peternakan Ayam Ras Petelur berdasarkan pencemaran air dengan menggunakan asumsi dasar interval kelas dan rentang kelas sebagai berikut:

Nilai maksimal $=$ Skor tertinggi $\mathrm{x}$ Jumlah sampel $\mathrm{x}$ Jumlah pertanyaan

$=5 \times 37 \times 1=185$

Nilai minimal $=$ Skor terendah $\mathrm{x}$ Jumlah Sampel $\mathrm{x}$ Jumlah pertanyaan

$=1 \times 37 \times 1=37$

Rentang Kelas $=$ Jumlah nilai tertinggi - Jumlah nilai terendah

Jumlah Skor $=185-37=29.65$

Dengan nilai tersebut dapat dibuat kategori sebagai berikut :

Sangat Terganggu : $155.4+29,6$

Terganggu : $125,6+29,6$

Cukup Terganggu : 96,2+29,6

Tidak Terganggu : 66,6 + 29,6

Sangat Tidak Terganggu : $37+29.6$ 


\section{a. Limbah}

Untuk mengukur persepsi masyarakat terhadap limbah usaha peternakan ayam ras petelur berdasarkan pengolahan limbah dengan menggunakan asumsi dasar interval kelas dan rentang kelas sebagai berikut :

Nilai maksimal $=$ Skor tertinggi $\mathrm{x}$ Jumlah sampel $\mathrm{x}$ Jumlah pertanyaan

$=5 \times 37 \times 2=370$

Nilai minimal $=$ Skor terendah $\mathrm{x}$ Jumlah Sampel $\mathrm{x}$ Jumlah pertanyaan

$=1 \times 37 \times 2=74$

Rentang Kelas $=$ Jumlah nilai tertinggi - Jumlah nilai terendah

Jumlah Skor $=370-74=60.85$

Dengan nilai tersebut dapat dibuat kategori sebagai berikut :

Sangat Terganggu : $317,2+60,8$

Terganggu : $256,5+60,8$

Cukup Terganggu : $195,6+60,8$

Tidak Terganggu : $134,8+60,8$

Sangat Tidak Terganggu : $74+60,8$

Nilai persepsi secara keseluruhan

Untuk mengetahui keseluruhan nilai dari persepsi masyarakat terhadap peternakan ayam ras petelur di Dusun Passau Timur, Desa Bukit Samang, Kecamatan Sendana, Kabupaten Majene, maka digunakan klasifikasi pengelompokan sebagai berikut :

Nilai maksimal $=$ Skor tertinggi $\mathrm{x}$ Jumlah sampel $\mathrm{x}$ Jumlah pertanyaan

$=5 \times 37 \times 4=740$

Nilai minimal $=$ Skor terendah $\mathrm{x}$ Jumlah Sampel $\mathrm{x}$ Jumlah pertanyaan

$=1 \times 37 \times 4=148$

Rentang Kelas $=$ Jumlah nilai tertinggi - Jumlah nilai terendah

Jumlah Skor $=740-148=118.4$

5

Dengan nilai tersebut dapat dibuat kategori sebagai berikut :

Sangat Terganggu : $621,6+118,4$

Terganggu : 503,2+118,4

Cukup Terganggu : $384,8+118,4$

Tidak Terganggu : $266,4+118,4$

Sangat Tidak Terganggu: $148+118,4$

\section{Hasil Dan Pembahasan}

Persepsi masyarakat adalah suatu proses penilaian seseorang terhadap objek tertentu berupa tanggapan yang diberikan oleh masyarakat mengenai peternakan ayam ras petelur yang berada di dusun passau, timur, desa bukit samang kecamatan sendana kabupaten majene. Indikator dari variabel penelitian ini adalah 1) Bau : aroma tidak sedap yang berasal dari peternakan ayam ras petelur; 2) Pencemaran air : pencemaran yang ditimbulkan peternakan ayam ras petelur; 3) Limbah : kondisi lingkungan dari peternakan ayam ras petelur yang tidak baik untuk dilihat oleh indera karena limbah tersebut hanya dibiarkan menumpuk. Persepsi masyarakat terhadap keberadaan peternakan ayam ras petelur dapat dijelaskan sebagai berikut:

\section{Bau}

Bau adalah aroma tidak sedap yang berasal dari peternakan ayam ras petelur sehingga masyarakat tidak tahan akan hal tersebut. Bau tersebut kadang kala ada biasa tidak tercium sebab bau muncul tergantung arah angin. Untuk melihat persepsi masyarakat Di Dusun Passau Timur Desa Bukit Samang Kecamatan Sendana Kabupaten Majene, dengan sub variabel bau dapat dilihat pada Tabel 6.

Tabel 6. Jawaban Responden Mengenai Persepsi Masyarakat Dengan Sub Variabel Bau Dusun Passau Timur Desa Bukit Samang kecamatan Sendana Kabupaten Majene.

\begin{tabular}{|c|c|c|c|c|c|}
\hline \hline Indikator & Kategori jawaban & $\begin{array}{c}\text { Nilai } \\
\text { skor }\end{array}$ & $\begin{array}{c}\text { Frekuensi } \\
\text { (orang) }\end{array}$ & Total & $\begin{array}{c}\text { Persentase } \\
(\%)\end{array}$ \\
\hline \hline \multirow{4}{*}{ Bau } & Sangat Terganggu & 5 & 0 & 0 & 0 \\
\cline { 2 - 6 } & Terganggu & 4 & 3 & 12 & 9,10 \\
\cline { 2 - 6 } & Cukup Terganggu & 3 & 6 & 18 & 16,21 \\
\cline { 2 - 6 } & Tidak Terganggu & 2 & 11 & 22 & 29,72 \\
\cline { 2 - 6 } & Sangat Tidak Terganggu & 1 & 17 & 17 & 45,94 \\
\hline Jumlah & & 37 & 69 & $100 \%$ \\
\hline
\end{tabular}

Tabel 10. Menunjukkan bahwa total skor untuk sub variabel bau diperoleh 69 skor dengan kategori tidak terganggu yang berarti berada pada kategori rendah. Diantara ketiga indikator dipreroleh nilai skor yang sangat tinggi yaitu 22 skor pada indicator tidak terganggu dengan adanya bau. rendahnya skor tersebut disebabkan karena sebagian besar masyarakat merasa tidak terganggu dengan adanya bau yang ditimbulkan dari peternakan ayam ras petalur tersebut. Hal ini sesuai dengan pendapat Sudarma dalam Rachman (2012), bahwa tanggapan seseorang terhadap bau yang tercium tergantung individu seseorang, karena bau peternakan berasal dari makanan, dan limbah. Untuk mendapatkan gambaran yang lebih jelas mengenai persepsi masyarakat terhadap keberadaan peternakan Ayam Ras Petelur dengan indikator bau dapat dilihat pada gambar1

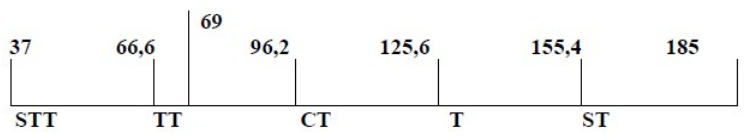

Gambar 1. Skala Persepsi Masyarakat Terhadap Keberadaan Peternakan Ayam Ras Petelur dengan Sub Variabel Bau.

Gambar 1. dapat dijelaskan bahwa total skor 69 untuk persepsi masyarakat terhadap keberadaan peternakan Ayam Ras Petelur skor $(66,6$ - 96,2) dengan kategori terganggu. Hal ini berarti bahwa menurut jawaban responden sebagian besar responden merasa terganggu dengan adanya bau. Karena bau tersebut muncul sesuai dengan arah datangnya angin. Hal ini sesuai pendapat Septianing dalam Rachman (2012) bahwa bau menyengat muncul jika hujan turun, maupun angin kencang.

\section{Pencemaran air}


Pencemaran air adalah kondisi lingkungan dari peternakan Ayam Ras Petelur yang tidak baik untuk dilihat oleh indera karena limbah cair tersebut hanya di buang begitu saja disaluran air di tempat pemukiman yang padat. limbah cair tersebut dibiarkan pada saluran pembuangan. Untuk melihat persepsi masyarakat Dusun Passau Timur Desa Bukit samang kecamatan sendana kabupaten majene. Mengenai persepsi masyarakat terhadap keberadaan peternakan Ayam Ras Petelur dengan sub variabel pencemaran air dapat dilihat pada Tabel 7.

\begin{tabular}{|c|c|c|c|c|c|}
\hline Indikator & Kategori jawaban & $\begin{array}{c}\text { Nilai } \\
\text { skor }\end{array}$ & $\begin{array}{c}\text { Frekuensi } \\
\text { (orang) }\end{array}$ & Total & $\begin{array}{c}\text { Persentase } \\
(\mathbf{\%})\end{array}$ \\
\hline \multirow{4}{*}{ Air berbau } & Sangat Terganggu & 5 & 0 & 0 & 0 \\
\cline { 2 - 6 } & Terganggu & 4 & 0 & 0 & 0 \\
\cline { 2 - 6 } & Cukup Terganggu & 3 & 0 & 0 & 0 \\
\cline { 2 - 6 } & Tidak Terganggu & 2 & 0 & 0 & 0 \\
\cline { 2 - 6 } & Sangat Tidak Terganggu & 1 & 37 & 37 & $100 \%$ \\
\hline Jumlah & & & 37 & 37 & $100 \%$ \\
\hline
\end{tabular}

Tabel 7. Menunjukkan bahwa total skor yang diperoleh yaitu 37 skor yang berarti berada pada kategori rendah. Diantara kedua indikator diperoleh nilai skor yang sangat tinggi yaitu 37 skor pada kedua indikator tersebut dengan kategori sangat tidak terganggu. Rendahnya skor tersebut disebabkan karena sebagian masyarakat di Dusun Passau Timur merasa sangat tidak terganggu dengan pencemaran air dikarenakan pembuangan limbah baik sehingga tidak meggagu pemukiman wargah. Hal ini sesuai pendapat Lahamma (2000) yang menyatakan bahwa harusnya ada pengolahan limbah yang benar agar tidak mengganggu warga dan limbah tersebut sebaiknya diolah agar tidak mencemari lingkungan. Untuk mendapatkan gambaran yang lebih jelas mengenai Persepsi Masyarakat Terhadap Keberadaan Peternakan Ayam Ras Petelur dengan sub variable pengolahan limbah dapat dilihat pada Gambar 3.

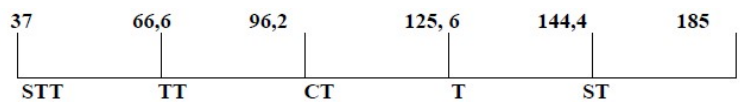

Gambar 1. Skala Persepsi Masyarakat Terhadap Keberadaan Peternakan Ayam Ras Petelur dengan Sub Variabel Pencemaran air.

Gambar 2 menunjukkan bahwa total skor 37 untuk persepsi masyarakat terhadap keberadaan Peternakan Ayam Ras Petelur dengan skor $(37-66,6)$ dengan kategori tidak terganggu. lingkungan dari peternakan ayam ras petelur yang tidak bagus untuk dilihat oleh indera pengelihatan (mata), dan penciuman (hidung) karena limbah tersebut hanya dibiarkan menumpuk. Untuk melihat persepsi masyarakat di Dusun Passau Timur Desa Bukit Samang Kecamatan Sendana Kabupaten Majene. mengenai persepsi masyarakat terhadap keberadaan peternakan ayam ras

\section{Limbah}

Limbah adalah kondisi petelur dengan sub variabel limbah dapat dilihat pada tabel 8 .
Tabel 8. Jawaban Responden Mengenai Persepsi Masyarakat Dengan Sub Variabel Pengolahan Limbah Di di Dusun Passau Timur Desa Bukit Samang Kecamatan Sendana Kabupaten Majene.

\begin{tabular}{|c|c|c|c|c|c}
\hline \hline Indicator & Kategori jawaban & $\begin{array}{c}\text { Nilai } \\
\text { skor }\end{array}$ & $\begin{array}{l}\text { Frekuensi } \\
\text { (orang) }\end{array}$ & Total & $\begin{array}{c}\text { Persentase } \\
(\mathbf{\%})\end{array}$ \\
\hline \hline \multirow{4}{*}{ Ditumpuk } & Sangat Terganggu & 5 & 2 & 10 & 5,40 \\
\cline { 2 - 6 } & Terganggu & 4 & 4 & 16 & 10,81 \\
\cline { 2 - 6 } & Cukup Terganggu & 3 & 14 & 36 & 37,83 \\
\cline { 2 - 6 } & Tidak Terganggu & 2 & 17 & 24 & 45,94 \\
\cline { 2 - 6 } & Sangat Tidak Terganggu & 1 & 0 & 0 & 0 \\
\hline Jumlah & & & 37 & 86 & $100 \%$ \\
\hline Indicator & Kategori jawaban & $\begin{array}{c}\text { Nilai } \\
\text { skor }\end{array}$ & $\begin{array}{c}\text { Frekuensi } \\
\text { (orang) }\end{array}$ & Total & $\begin{array}{c}\text { Persentase } \\
(\mathbf{\%})\end{array}$ \\
\hline \multirow{3}{*}{$\begin{array}{c}\text { Kurangnnya } \\
\text { kebersihan }\end{array}$} & Sangat Terganggu & 5 & 1 & 5 & 2,70 \\
\cline { 2 - 6 } & Terganggu & 4 & 4 & 16 & 10,81 \\
\cline { 2 - 6 } & Cukup Terganggu & 3 & 15 & 45 & 37,87 \\
\cline { 2 - 6 } & Tidak Terganggu & 2 & 17 & 14 & 45,94 \\
\cline { 2 - 6 } & Sangat Tidak Terganggu & 1 & 0 & 0 & 0 \\
\hline Jumlah & & & 37 & 80 & $100 \%$ \\
\hline \multicolumn{2}{|c|}{ Total } & & & 166 & \\
\hline
\end{tabular}

Sumber : Data Primer Setelah Diolah, 2017.

Tabel 8 menunjukkan bahwa total skor yang diperoleh yaitu 166 skor yang berarti berada pada kategori rendah, meskipun demikian dari indikator yang terdiri dari ditumpuk dikolam pembuangan dan kurangnya kebersihan. Diantara kedua indikator diperoleh nilai skor yang sangat tinggi yaitu 45 skor pada kedua indicator kurangnnya kebersihan tersebut dengan kategori cukup terganggu. Tinggi skor tersebut disebabkan karena sebagian masyarakat di Dusun Passau Timur merasa terganggu dengan pengolahan limbahnya yang masih kurang bagus karena fesesnya hanya dibiarkan disaluran pembuangan saja. Hal ini sesuai dengan pendapat Sudarma dalam Rachman (2012), yang mengatakan bahwa limbah ternak adalah suatu sumber daya yang bila tak dimanfaatkan dengan baik, dapat menimbulkan masalah bagi peternak itu sendiri maupun terhadap lingkungan. Semua limbah peternakan adalah bahan yang dapat diperbaharui (renewable), tak akan habis selama ternak ada. Bila limbah peternakan tidak dikelola dengan baik akan mencemari atau memperburuk kondisi lingkungan setempat. Untuk mendapatkan gambaran yang lebih jelas mengenai persepsi masyarakat terhadap keberadaan peternakan ayam ras petelur dengan sub variabel limbah dapat dilihat pada Gambar 3.

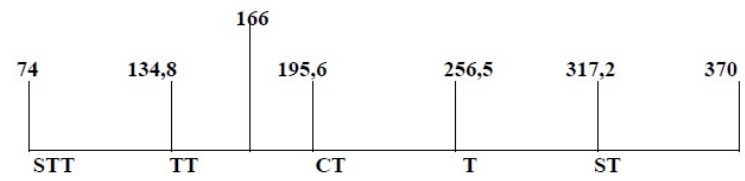

Gambar 3. Skala Persepsi Masyarakat Terhadap Keberadaan Peternakan Ayam Ras Petelur Dengan Sub Variabel Limbah.

Dari gambar 3 dapat dijelaskan bahwa total skor 166 untuk persepsi masyarakat terhadap keberadaan peternakan ayam ras petelur dengan skor $(134,8-195,6)$ dengan cukup kategori tidak terganggu 


\section{Total Persepsi Secara Keseluruhan}

Penilaian masyarakat di Dusun Passau Timur Desa Bukit Samang Kecamatan Sendana Kabupaten Majene terhadap persepsi secara keseluruhan dapat dilihat pada Tabel 9.

Tabel 9. Hasil Rekapitusi Penilaian Masyarakat Terhadap Persepsi di di Dusun Passau Timur Desa Bukit Samang Kecamatan Sendana Kabupaten Majene.

\begin{tabular}{llll}
\hline \hline Variable & Sub variable & nilai & Keterangan \\
\hline \hline Persepsi masyarakat & 1. Bau & 69 & Sangat tidak Terganggu \\
& 2. Pencemaran air & 37 & Sangat tidak Terganggu \\
& 3. Limbah & 166 & Tidak terganggu \\
\hline Jumlah & & 272 & \\
\hline
\end{tabular}

Tabel 9 menunjukkan bahwa hasil penilaian responden terhadap persepsi secara keseluruhan adalah tidak terganggu dengan total bobot 272 Penilaian tersebut meliputi bau dengan indikator bau, tidak mudah hilang, dan sangat menyegat dengan bobot 69 , pencemaran air dengan indikator air berbau dan saluran air dengan bobot 37 limbah dengan indikator di tumpuk dan kurangnya kebersihan dengan bobot 166 . Untuk mendapatkan gambaran yang lebih jelas mengenai persepsi secara keseluruhan dapat dilihat pada gambar 4 .

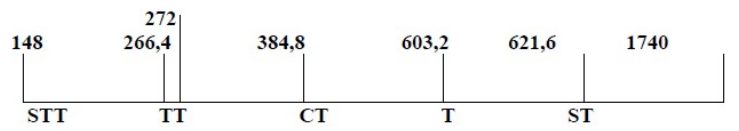

Gambar 5 menujukkan bahwa jumlah skor sebanyak 272 untuk persepsi masyarakat secara keseluruhan skor $(266,4-384,8)$ termasuk kategori tidak terganggu. Hal ini berarti bahwa responden merasa tidak terganggu

dengan keberadaan peternakan ayam ras petelur dikarenakan peternakan ayam ras petelur tersebut berada di dekat pemukiman penduduk serta kurang memperhatikan kebersihan. diketahui bahwa untuk mendirikan peternakan harus jauh dari pemukiman penduduk agar tidak mengganggu kenyamanan masyarakat yang tinggal di Dusun Passau Timur sesuai dengan data bahwa sub variabel bau responden merasa sangat terganggu, pencemaran air pada kategori cukup terganggu dan limbah pada kategori terganggu. Hal ini sesuai dengan pendapat Sihombing (2000) yang menyatakan bahwa, bangunan kandang harus cukup jauh jaraknya dari rumah-rumah pemukiman untuk menghindari kebisingan, udara dan air bagi penghuni rumah tempat tinggal, bangunan-bangunan atau pusatpusat kegiatan berjarak 200 meter lainnya.

\section{Kesimpulan}

Persepsi masyarakat terhadap keberadaan peternakan ayam ras petelur di Dusun Passau Timur Desa Bukit Samang Kecamatan Sendana Kabupaten Majene. sebagian besar merasa tidak terganggu dengan adanya peternakan ayam ras petelur

\section{Daftar Pustaka}

Anwar A.A, 2012. Persepsi Masyarakat terhadap Keberadaan Peternakan Burung Puyuh di Kecamatan pallangga Kabupaten Gowa (Skripsi) Fakultas Universitas Hasanuddin. Makassar.

Badan pusat statistic. (BPS) 2015. Jumlah Populasi Ayam Ras Petelur di Indonesia.

Daniel, M. 2004. Pengantar Ekonomi Pertanian. Bumi Aksara, Jakarta.

Dangnga, M, S. 1992. Persepsi Remaja Terhadap Perkawinan Ideal Di Kotamadya Pare-Pare. Universitas Hasanuddin, Makassar.

Hadi, 2009. Aspek Sosial Amdal: Sejarah, Teori dan Metode. Gajah Mada University Press, Yogyakarta.

Irawan, 2001. Manajemen Prinsip dan Kasus. PT. BPFE. Universitas Indonesia, Yogyakarta.

Masnellyarty. 1992 aturan amdal university Indonesia, Yogyakarta.

Mustansyir, R dan Munir, M. 2003. Filsafat Ilmu. Pustaka Pelajar, Yogyakarta.

Rachmat, Jalaluddin. 2001. Psikologi Komunikasi. Remaja Rosdakarya. Bandung.

Riduwan, 2008. Skala Pengukuran VariabelVariabel Penelitian. Penerbit Alfabeta, Bandung.

Sunarto. 2003. Perilaku Konsumen. Penerbit Amus, Jakarta.

Simamora,B. 2002. Prilaku Konsumen dan KomunikasiPemasaran. Rosdakarya. Bandung.

Sianturi. 2011, Menurut Keputusan Mentri Pertanian Pemerintah Republik Indonesia.

Soehadji, 1992. Kebijakan Pemerintah dalam Industri Peternakan dan Penanganan Limbah Peternakan. Direktorat Jenderal Peternakan, DepartemenPertanian. Jakarta.

Sugiyono, 2003. Statistik Untuk Penelitian. Alfabeta, Bandung.

Umar, H. 2003. Metode Penelitian Untuk Skripsi dan Tesis Bisnis. Raja Grafindo Persada, Jakarta. 